\title{
MARRIAGE AND FAMILY LIFE IN THE JURISPRUDENCE OF THE EUROPEAN COURT OF HUMAN RIGHTS O. Ghiță
}

\section{Oana Ghiță}

Faculty of Law and Social Sciences, Law Department

University of Craiova, Craiova, Romania

"Correspondence: Oana Ghiţă, University of Craiova, Faculty of Law and Social Sciences, 107 D Calea Bucuresti St., Craiova Romania

E-mail: ghita.oana@gmail.com

\section{Abstract}

The article 8 and 12 - European Convention of Human Rights regulate the right to family and private life and, respectively, the right to marriage. These rights have been transposed into the national legislation of the States-members of European Union. The two rights that we are speaking of, which can be found as a constitutional principle and as an ordinary law, tries to reduce the public authorities interference into the private and personal family field. The reality proves that the right to marriage has been broken by the impossibility of the spouses to marry because they can not be divorced. This is the reason why we have two different rights in European Convention: the right to private, family life and the right to marriage.

Many European states still have a limited regulation of the reasons for getting the dissolution of marriage. The European Convention has nothing to do with such cases because does not regulates the right to divorce and it would be an interference into the national law. How can a person be married again if he/she doesn't have the possibility to divorce? In these conditions, can we take the European Convention into consideration as a real instrument of protection for the right to marriage?

The first precedent of ECHR jurisprudences limits the infringement of the right to marriage made by the national Courts because of the lack of regulations or a bad interpretation of it.

\section{Keywords: ECHR, right to marriage, family life, divorce, separation of the spouses.}

\section{Introduction}

From the multitude of laws guaranteeing the right to private and family life and the right to marriage we turn our attention to Articles 8 and 12 of the European Convention on Human Rights.

The way in which these legal texts create the necessary levers of the rights considered here must be subordinated to the incapability of EU rules to interfere with national laws, especially in a matter so fraught with personal and private aspects. Moreover, we believe that these rights are extremely difficult to break into the national legal maze, being a corollary of the principles established in the field of family relationships which are loaded with tradition, morality, religion and social aspects. ${ }^{1}$ Standardization of such rules, even when tested by numerous projects in Europe, was not successful, given the opposition from the content of legal texts from national legal systems.

\section{The Scope of Articles 8 and 12 of the European Court of Human Rights}

A number of international laws govern the right to marry and right to found a family, linking them in the same law. Thus, Article 9 of the Charter of Fundamental Rights of the European Union: "The right to marry and right to found a family shall be guaranteed in

\footnotetext{
${ }^{1}$ Ioana Nicolae, Instituţii ale dreptului familiei, Hamangiu Publishing House, Bucharest, 2009, p. 142 and the others.
} 
accordance with the national laws governing the exercise of these rights"; Article 16 of the Universal Declaration of Human Rights "Men and women of full age, without any limitation due to race, nationality or religion, have the right to marry and to found a family."; Article $23 \S 2$ of the International Covenant on Civil and Political Rights of 1966: "The right of men and women of marriageable age to marry and to found a family shall be recognized."; the same effect is the art. 8 European Convention on Human Rights:" Everyone has the right to respect for his private and family life, his home and his correspondence. There shall be no interference by a public authority with the exercise of this right except such as is in accordance with the law and is necessary in a democratic society in the interests of national security, public safety or the economic wellbeing of the country, for the prevention of disorder or crime, for the protection of health or morals, or for the protection of the rights and freedoms of others. Commission and the European Court of Human Rights: "Article 12, in fact, provides for the right to marry and to found a family as a single law. (...) [It] actually recognizes the right of men and women, of an age when they consent to start a family and have children. The existence of a couple is fundamental."

The right protected by Article 8 namely the right to private and family life, home and correspondence, is part of the conditional rights, which, relative to other rights under the Convention - such as the right to life or the right not to be subjected to inhuman or degrading treatment - may be subject to limitations.

Thus, after paragraph 1 of Article 8 provides that everyone has the right to respect for their private and family life, home and correspondence, the second paragraph shall determine the limits that may be made to such rights. The conditions are thus listed under which a public authority can intervene as it is necessary for the interference to be stipulated by national law, constitute a necessary measure in a democratic society, for national security, public safety or the economic well-being of the country, prevention of disorder or facts criminal protection of health or morals, or the protection of rights and freedoms of others. These conditions expressly set out in the text of the Convention combine with the jurisprudence of the Court keeping in mind in addition that the interference must be proportionate to the aim pursued. ${ }^{2}$

Determining the application limits of Article 8 we need to consider also the limits imposed by establishing the scope of Article 8, the meaning given notions of "private life", "family", "home" and "correspondence" varying in time and space from state to state and even within the same state from one social group to another.

These texts confirmed by the judgments of the European Court on this topic lead us to the idea that a "cause-purpose" report is determined, in which the cause is the marriage, and the purpose is founding family. Separating the right "to marry" from the right "to start a family" would mean making the former "theoretical and illusory", , an end in itself, would mean reducing it to a mere symbol. However, it is unthinkable to tell someone that they have the right to marry, but to start a family. "Marriage without a family purpose is nothing than a private relationship publicly. Family without her support legal marriage no longer contribute to the common good of society, it becomes a simple private good couple."4

Article 12 of the European Convention on Human Rights guarantees the right to marry and to found a family within the same fundamental right, indicating: "Men and women of marriageable age have the right to marry and to found a family, according to the national laws governing the exercise of this right." Likewise, the European Court of Human Rights (ECHR) clearly states that "the right to marry guaranteed by Article 12 refers to the traditional marriage

\footnotetext{
2 Sonia Cososchi, Limitãri ale drepturilor garantate de art. 8 din Convenţia Europeana a Drepturilor Omului, http://soniacososchi.blogspot.ro/2008/10/limitele-de-aplicare-ale-art-8-din.html

Airey c. Irlandei, nr. 6289/73, Decision from 9 October 1979, § 24; Scoppola c. Italia (nr.2), GC, nr. 10249/03, Decision from 17 September 2009, § 104 and desident opinions.

4 Andreea Popescu, Dreptul bărbatului şi al femeii de a întemeia o familie, European Centre for Law and Justice, ECLJ, 2013, p. 6 and the following.
} 


\section{O. Ghiţă}

between two persons of different biological sex. This follows from the wording of Article 12, which clearly indicates that it protects marriage as the foundation of the family."

We can see that the texts of conventions and treaties at a European level uniformly enshrines the right to marry and the right to start a family, but following the social realities we can easily distinguish the existence of the family without the existence of marriage. It is possible that the family is actually based on simple relationships, in which the couple can give birth to children. Following the Court jurisprudence we can see that there is a broadening of the notion of "family life" from the relations between spouses to which children are added, and at present they are extended to de facto relationships, where bonds and manifestations of affection render the characteristics of family life, even if it is about a marriage ceremony. In Case X, Z, Y vs. The United Kingdom ${ }^{6}$, the Court has presented some of the elements that must be considered when analyzing the existence or not of family life. Thus, members cohabitating over a period of time, a child born to or perhaps adopted by the couple in question, the personal ties between parents and children, all represent such items as "turns" de facto family in a family according to the meaning of the European Court of Human Rights.

What happens when even if these elements are met, a family cannot be acknowledged as such because it is not offered the necessary leverage to respect this legal requirement? Acknowledging a family de facto, does not mean you restrict the opportunity for it to be one de jure. This situation may arise under the European Convention on Human Rights guarantees the right to divorce, thus limiting the right to marry or, in other words not protecting the right to a first marriage.

In a more specific and general way, the right to respect family life and the right to marry causes the establishment of an obligation within the state related to means. ${ }^{7}$ The state must "act to enable the persons concerned to lead a normal family life." 8

The Limitations of Rights Enshrined in Article 8 and Article 12 of the European Court of Human Rights - The Lack of a Guarantee in the Completion of a New Marriage

Article 12 does not guarantee in any way the right to divorce. The European Court clearly declines to conduct an "evolutionary interpretation" of the Convention to extract a right which was not inserted in it from the beginning and considers that the right to marriage refers to establish the conjugal relations and not to dissolute them. In their common meaning, the words "right to marry" in Article 12 refer to forming conjugal relations and not dissolving them. Moreover, the preparatory work of this article reveals no intention to incorporate a certain guarantee to the right to divorce. The Court would not know how to draw from it, through evolutionary interpretation, a right that has been deliberately omitted from the beginning, if the Convention were interpreted in the context of today. It shows that the Convention must be read as a whole. We can not agree that such a right can result from Article 8, while not resulting from art. 12. Thus the Court rejects a petitioners' claim that they are victims of discrimination which is contrary to Article 14 of the Convention. 8 in combination with Article 8 due to the fact that Irish law may recognize some divorces granted abroad. In its conception, it cannot be considered as similar to the situation of petitioners and that the people who can get this recognition. ${ }^{9}$

All these things considered, European case law establishes a right of married couples to live separately if their marriage fails. Supported by positive obligations in relation to Article 8

\footnotetext{
5 Sheffield and Horsham vs. Great Britain, nr. 22985/93 şi 23390/94, Decision from 30 July 1998.

6 X.Y.Z. vs. Great Britain, Decision from 22 April 1997, par. 36, www.echr.coe.int.

7 Fr. Sudre, Drept european şi internaţional al drepturilor omului, Editura Polirom, Bucharest, 2006, p. 336.

8 Marckx vs. Belgia, nr. 6833/74, Decision from 13 June 1979, Strasbourg, http://hudoc.echr.coe.int/sites/eng/pages/search.aspx?i=001-57534\#\{\%22itemid\%22:[\%22001-57534\%22]\}

9 Johnston and others vs Irland, nr. 9697/82, Decision from 18 December 1986,

http://jurisprudentacedo.com/JOHNSTON-c.-IRLANDEI-Interdictie-constitutionala-a-divortului-in-Irlanda-siconsecinte-juridice-care-decurg-de-aici-pentru-un-barbat-si-o-femeie-necasatoriti-impreuna-precum-si-pentrucopilul-lor.html
} 
from the Convention, the European Court building considers, indeed, that the separation of the spouses should get a "legal consecration" and "privacy and family can sometimes require the means to spare the spouses from the obligation of living together."10

Moreover, Article 12 is not subject of the specific limitations of the public policy clause, as is the case of Article 8, but entrusts the national legislation with the regulation of the right to marry. Under European law, national law must not restrict or limit this right in a manner that would undermine "its very substance." "If the rules of law recognize divorce, the right of a person to remarry should not be limited in this "unreasonable" way.

Such a situation is found in Swiss law which regulates the prohibition to remarry for a period of three years after the divorce imposed on the spouse liable for the divorce (F. vs. Switzerland, 18 December 1987)

A similar situation, a law that unduly restricts the right to marry is found in Bulgaria. In this legal system, divorce was permitted only in two cases, namely when marital relationship break up and divorce by consent of the spouses. In the case here cited ${ }^{12}$, after they were married in 1986, as a student, the plaintiff and his wife separated in fact after the latter graduated and returned to her hometown in northern Bulgaria with two children born to the marriage. Relations between the couple cooled considerably, so the wife asked the court for alimony for her two children, the pension was granted.

Upon graduation, the plaintiff moved in with another woman to a town in southern Bulgaria, in 2002, and had another child. Wanting to remarry, the husband filed a divorce action in contradiction with his wife. She argued that the divorce not be granted, however, since she and her husband were married and she is not responsible for their separation in fact, was convinced that reconciliation with her husband was still possible in the interests of the two children; instance court dismissed the application for divorce, given the national legislation at the time. The first instance court held that "dissolution of conjugal life of the couple was due to unacceptable behavior" of her husband. The appeals have pointed out the "disagreements between the couple which hitherto prevented a reconciliation between spouses were not "insurmountable". 13

Any attempt to divorce by consent of both spouses was vehemently rejected by the wife.

When the case came to the European Court of Human Rights, it invoked the principle of subsidiary, according to which "it cannot substitute national courts in the determination of facts and interpretation of law" (see, to that effect, JH and other 23 vs. France, November 24, 2009, nr. 49637/09). The Court also concluded that national courts have complied with their obligation to properly motivate rulings on divorce proceedings brought by the applicant. The Court noted that although the applicant argued that the relationship with his wife was deeply and irrevocably altered long time since they were separated in fact he has a new girlfriend and they live together and had a child together with national courts note that the only disagreement between spouses was pertaining to establishing a joint residence and therefore surmountable. The responsibility for altering marital relationship between spouses was again laid at the applicant's door and in motivating its decision; the Court answered the applicant's claims with arguments based on evidence in the file.

However, the Court reiterated that neither Article 8 nor Article12 of the Convention guarantees the right to divorce (Johnston and others vs. Ireland), but recognizing the right to divorce is not equivalent to the absence of any conventional protection. The Court has repeatedly addressed the implementation of divorce proceedings, identifying elements that could affect the effectiveness of the right to marry, so that it comes to a situation where, although a right is

10 Ibidem.

Christine Goodwin vs. Great Britain, nr. 28957/95, Decision from 11 July 2002, www.echr.coe.int.

Ivanov and Petrova vs. Bulgariei, Decision from 14 June 2011, www.echr.coe.int

Lavinia Cîrciumaru, Ionuţ Militaru, Dreptul la divorț (Article 6, 8 and 12 European Court of Human Rights): Imposibilitatea unei persoane de a se recăsători izvorâtă din refuzul pronunţării divorţului pentru prima căsătorie, JurisClasor CEDO Journal, University Publishing House, Bucharest, 2012, p. 27-30. 


\section{O. Ghiţă}

neither recognized nor guaranteed by the Convention, i.e. the right to divorce), he has a certain protection indirectly. ${ }^{14}$

Firstly, although the law provides for divorce, Article 12 of the Convention guarantees the right of divorced persons to remarry without suffering unreasonable restrictions in the state law that has emerged in the case law of the European Court of Human Rights because of F. vs. Switzerland. ${ }^{15}$

Secondly, by violating the principle of celerity of divorce proceedings may raise the issue of infringement of Article 12 of the Convention ${ }^{16}$, but in this case, none of these cases was considered applicable because it was not thought as a temporary restriction to remarry after divorce or of excessive length of proceedings for divorce.

Throughout time, the Court stressed that the Convention cannot be interpreted as granting entitlement for divorce and even less of a favorable outcome in this case.

In this case, the Court ruled that the dismissal of divorce was not based on opposition husband have not come to dissolution of marriage, but without finding a deep and irreversible deterioration of the marital bond. Court noted that national judges felt the "de facto separation of the couple was not an insurmountable obstacle for the spouses and therefore the relations between them were irreparably damaged." The Court also ruled that implications of property and inheritance or restrictions on alienation of common property as a result of maintaining marriage is nothing more than the logical consequences of his rejection of the divorce request that are subject to national regulation on property relations between spouses. At the same time, it was rejected by the Court and the complaint filed by the plaintiff's concubine, who has not invoked the general prohibition to marry, but the impossibility of concluding a civil marriage first applicant on the ground that prevent the marriage of the two plaintiffs was the result of a general prohibition, but stems directly from the rejection of the divorce for good reasons - the application for divorce brought by the plaintiff and the application of the law of the principle of monogamy.

\section{Conclusions}

From this analysis of these concrete cases brought before European Court of Human Rights because of violations of Articles 8 and 12 of the Convention, we see the balance that the Court tries to guarantee between the exercise of rights as prescribed by the Convention and limiting all interference that it may have with the national laws of Member States. Even if the right to divorce is not provided in the Convention, along with other items mentioned within it (e.g. Article 6 concerning the right to a fair trial), no more than an indirect protection of this right was managed. Respecting procedural elements and the way national courts have justified their judgments have most often been analyzed. Not recognizing the right to divorce does not equal the absence of any conventional protection.

However, we believe that from case to case, the Court should consider the context in which manner is guaranteed the right to marry and that the limits imposed by the "impossibility of interference" meet certain prerequisites: to be provided by law; to constitute a necessary measure in a democratic society; for national security, public safety or the economic well-being of the country, prevention of disorder or crime, the protection of health or morals, or the protection of rights and freedoms of others; to be proportionate to the aim pursued. However, even though throughout time, the Court jurisprudence was formed in supporting the right to marriage and not its dissolution, we consider this as the only guarantee of a first marriage and the right not to remarry, the latter remains suspended between gaps of laws national and the

\footnotetext{
14 Valérie Gas and Nathalie Dubois vs. France, August 31, 2010, nr. 25951/07, RR vs. Poland, May 26, 2011, nr. 27617/04, http://www.hotararicedo.ro/index.php/news/2011/06/dreptul-la-divort-art.-6-8-i-12-cedo-imposibilitateaunei-persoane-de-a-se-recasatori-izvorat-din-refuzul-pronuntarii-divortului

15 Lavinia Cîrciumaru, Ionuţ Militaru, op. cit., p. 27-30.

16 Aresti Charalambous c. Ciprului, 19 July 2007, nr. 43151/04; Wildgruber c. Germaniei, requests nr. $42402 / 05$ and 42423/05.
} 
restrictive interpretation of the text of Articles 8 and 12 from the European Court of Human Rights.

\section{References:}

- Popescu, Dreptul bărbatului şi al femeii de a întemeia o familie, European Centre for Law and Justice, ECLJ, 2013;

- Lavinia Cîrciumaru, I. Militaru, Dreptul la divorţ (Article 6, 8 and 12 European Court of Human Rights): Imposibilitatea unei persoane de a se recăsători izvorâtă din refuzul pronunţării divorţului pentru prima căsătorie, JurisClasor CEDO Journal, University Publishing House, Bucharest, 2012;

- Ivanov and Petrova vs. Bulgariei, Decision from 14 June 2011, http://www.hotararicedo.ro/index.php/news/category/hotarari-relevante/10.

- Wildgruber vs. Germaniei, requests nr. 42402/05 and 42423/05, http://www.hotararicedo.ro/index.php/news/2011/06/dreptul-la-divort-art.-6-8-i-12-cedoimposibilitatea-unei-persoane-de-a-se-recasatori-izvorat-din-refuzul-pronuntarii-divortului

- Valérie Gas and Nathalie Dubois vs. France, August 31, 2010, nr. 25951/07, RR vs. Poland, May 26, 2011, nr. 27617/04, http://www.hotararicedo.ro/index.php/news/2011/06/dreptul-ladivort-art.-6-8-i-12-cedo-imposibilitatea-unei-persoane-de-a-se-recasatori-izvorat-dinrefuzul-pronuntarii-divortului

- Ioana Nicolae, Instituţii ale dreptului familiei, Hamangiu Publishing House, Bucharest, 2009;

- Sonia Cososchi, Limitãri ale drepturilor garantate de art. 8 din Convenţia Europeana a Drepturilor Omului, http://soniacososchi.blogspot.ro/2008/10/limitele-de-aplicare-ale-art-8din.html;

- Aresti Charalambous vs. Ciprului, 19 July 2007, nr. 43151/04, http://www.hotararicedo.ro/index.php/news/2011/06/dreptul-la-divort-art.-6-8-i-12-cedoimposibilitatea-unei-persoane-de-a-se-recasatori-izvorat-din-refuzul-pronuntarii-divortului;

- Fr. Sudre, Drept european şi internaţional al drepturilor omului, Editura Polirom, Bucureşti, 2006;

- Christine Goodwin vs. Great Britain, nr. 28957/95, Decision from 11 July 2002, www.echr.coe.int;

- Sheffield and Horsham vs. Great Britain, nr. 22985/93 și 23390/94, Decision from 30 July 1998;

- X.Y.Z. vs. Great Britain, Decision from 22 April 1997, par. 36, www.echr.coe.int.;

- Johnston and others vs Irland, nr. 9697/82, Decision from 18 December 1986, http://jurisprudentacedo.com/JOHNSTON-c.-IRLANDEI-Interdictie-constitutionala-adivortului-in-Irlanda-si-consecinte-juridice-care-decurg-de-aici-pentru-un-barbat-si-ofemeie-necasatoriti-impreuna-precum-si-pentru-copilul-lor.html;

- Airey c. Irlandei, nr. 6289/73, Decision from 9 October 1979, § 24; Scoppola c. Italia (nr.2), GC, nr. 10249/03, Decision from 17 September 2009, § 104 and desident opinions;

- Marckx vs. Belgia, nr. 6833/74, Decision from 13 June 1979, Strasbourg, http://hudoc.echr.coe.int/sites/eng/pages/search.aspx?i=00157534\#\{\%22itemid\%22:[\%22001-57534\%22]\}. 